\title{
Worthy of Rejection: Copyright as Community
}

\section{Property}

\author{
Carla M. Roberts*
}

In the 1987 decision In re Marriage of Worth, ${ }^{1}$ a California Court of Appeal held for the first time that ownership of a copyright was a community property ${ }^{2}$ asset. Under the court's ruling, a nonauthor spouse now has rights as a joint owner of the copyright, in addition to rights to income derived from a work produced during a marriage. ${ }^{3}$ Because joint owners have the right under the Copyright Act ${ }^{4}$ to license copyrights independently of their co-owners, the Worth decision creates significant uncertainty in the entertainment industry by calling into question the validity of copyright transfers that are not jointly executed by copyright transferors and their spouses.

Part I of this Note explains the Worth holding and its impact, and outlines the general principles of copyright protection and community property. Part II argues that ownership of a copyright should not be treated as community property because such treatment provides a disincentive for authors to create works, and thereby conflicts with the purposes of federal copyright law. Part III argues that treating ownership of a copyright as a community property asset is unconstitutional under the commerce clause ${ }^{5}$ because such treatment creates an impermissible burden on interstate transfers of copyright.

* The author dedicates this Note to her mother, Dr. Carmel Mary Roberts, who always believed.

1. 195 Cal. App. 3d 768, 241 Cal. Rptr. 135 (1987).

2. Eight states have community property systems by which spouses share ownership of all assets and income acquired during a marriage: Arizona, California, Idaho, Louisiana, Nevada, New Mexico, Texas, and Washington. 11 B. WITKIN, Community Property, in SUMMARY OF CALIFORNIA LAW § 1, at 374 (9th ed. 1990); see infra, Subsection I.C.2. Most states, including California, allow some modification of this formula by antenuptial agreements regarding property ownership. See W. MCCLANAHAN, COMMUNITY PROPERTY LAW IN THE UNITED STATES $\S 4: 18$ (1982 \& Supp. 1989).

3. This Note distinguishes between two elements inherent in ownership of a copyright: the right to income from a copyright, and the right to control the disposition of a copyright. Copyright law grants both of these rights to the author. Worth establishes for the first time a community property interest in the control element. This Note argues that it is appropriate to treat the right to income element as community property, but that it is inappropriate, and impermissible under the commerce clause, to treat the control element as community property. This Note uses the term "ownership of a copyright" to refer to the control element, and the term "rights to income" to refer to the income element.

4. 17 U.S.C. $\$ \S 101-914$ (1988) [hereinafter the Act].

5. "The Congress shall have Power ... To regulate Commerce with foreign Nations, and among the several States, and with the Indian Tribes ...." U.S. CoNST. art. I, \& 8, cl. 3. 


\section{THE CALIFORNIA HOLdING: IN RE MARRIAGE OF WORTH}

The Worth case required the application of two distinct bodies of law: federal copyright law and California community property law. ${ }^{6}$ The result-treating ownership of a copyright as a community property asset-creates enormous problems.

\section{A. The Worth Decision}

Worth involved two trivia books written, published, and copyrighted by Frederick Worth during his marriage to Susan Worth. Upon dissolution of their marriage in 1982, the Worths' settlement agreement stipulated that all income derived from these books would be divided equally between them. In 1984, Frederick sued the makers of the board game Trivial Pursuit for copyright infringement, asserting that they had plagiarized his books in some of the game's questions. ${ }^{7}$ On the basis of the interlocutory divorce decree, Susan sued for and received a court order entitling her to one-half of any proceeds Frederick might receive from his copyright infringement lawsuit. ${ }^{8}$ On appeal, the California Court of Appeal held not only that Susan was entitled to one-half of the proceeds of the litigation (as income generated by work done during their marriage), but also that Susan, by operation of California marital law, was a co-owner of the copyright itself, with all the rights of a joint owner under federal copyright law. ${ }^{9}$

\section{B. The Impact of Worth}

The ruling in Worth renders the requirements for a valid transfer of a copyright $^{10}$ ambiguous. This is partly because the Worth court left unclear whether transfers of community property copyrights are to be governed by California community property law or federal copyright law. Because the two

6. This Note focuses on California because (1) Worth, the only case to address this issue as yet, was decided in Califormia, and (2) California is the community property state most involved in the entertainment industry, where the ramifications of Worth will be most deeply felt. A similar ruling, however, is possible in all community property states. See supra note 2.

7. Worth v. Selchow \& Righter Co., 827 F.2d 569 (9th Cir. 1987), cert. denied, 108 S. Ct. 1271 (1988).

8. In re Marriage of Worth, 195 Cal. App. 3d 768, 771, 241 Cal. Rptr. 135, 135 (1987).

9. Id. at 774, 241 Cal. Rptr. at 137.

10. The Act defines a "transfer of copyright ownership" as "an assignment, mortgage, exclusive license, or any other conveyance, alienation, or hypothecation of a copyright or of any of the exclusive rights comprised in a copyright, whether or not it is limited in time or place of effect, but not including a nonexclusive license." 17 U.S.C. $\$ 101$ (1988). This Note uses the term "transfer" in its generic sense to refer to any of the above copyright conveyances, including a nonexclusive license. This Note uses the terms "exclusive transfer" to mean a transfer included in the section 101 definition of "transfer of copyright ownership", and "nonexclusive transfer" to mean a nonexclusive license specifically excluded from the section 101 definition. 
transfer standards are different, buyers cannot be certain that a transfer is valid unless both standards are met.

Under either standard a single co-owner can license nonexclusively without the consent of the other co-owner or owners. Under the federal copyright standard, both co-owners must execute an exclusive license for the transfer to be valid, whereas under the community property standard either co-owner may execute a valid exclusive transfer. Under Worth, then, the federal copyright standard dictates that no exclusive transfer executed by an author-past, present, or future-is valid ${ }^{11}$ without (1) the signature of the nonauthor spouse, ${ }^{12}$ or (2) proof that the author was single at the time a work was produced. ${ }^{13}$ The community property standard dictates that past exclusive transfers executed by the author spouse remain valid. However, the community property standard allows a nonauthor spouse to license a work exclusively without the author's knowledge or consent, as long as the nonauthor spouse's transfer was executed first.

Regardless of which transfer standard is used, buyers of copyrights must now take precautions against the dilution problem, where, prior to the execution of an exclusive transfer, the nonauthor spouse licenses a work nonexclusively, thus eliminating the availability of exclusive rights. If the community property standard is used, buyers must now be concerned about the sale-out-from-under problem, where the nonauthor spouse executes an exclusive license, thereby leaving the author spouse without the power to transfer any rights in the work. If the federal copyright standard is used, buyers now must contend with the veto problem, where the nonauthor spouse is able to prevent the sale of exclusive rights by refusing to sign the transfer contract.

For future deals, buyers negotiating with an author spouse now need to investigate whether prior transfers by the nonauthor spouse exist, because such transfers-unknown to the author spouse-will invalidate new ones. For deals executed prior to Worth, buyers cannot be certain that exclusive transfers remain valid, although prior nonexclusive transfers will be unaffected. In the

11. Being certain that a transferor owns the rights being purchased-and thus has the power to make a valid transfer-has always been a problem for copyright transferees. To address this problem, copyright purchasers typically include standard contractual covenants in which the transferor warrants ownership and indemnifies the purchaser. See, e.g., Publishing Agreement, in SELECTIONS FOR CONTRACTS 165 (E. Farnsworth \& W. Young eds. 1988). Where covenants of this type are regularly used, Worth merely increases the burden and the stakes for the purchaser. Transferees now have the burden of investigating the marital history of transferors, and altering these standard contractual warranties to account for Worth. The issue is not whether purchasers can contractually protect themselves from the effects of Worth. Rather, it is the fact that California is causing citizens of other states to take these measures to protect themselves from the effects of California law.

12. As used in this Note, "nonauthor spouse" refers either to a current spouse or to a former spouse who was married to the author at the time a work was produced, and as such is a co-owner under Worth.

13. This discussion applies with equal force to married owners who buy copyrights individually (as opposed to corporations who buy copyrights). Ownership by a married buyer would also be subject to Worth, and therefore would involve the same kinds of practical problems. This Note focuses on the situation of ownership by authors, because treating copyright as community property is more troubling in this context, and the arguments against such treatment more compelling, due to the issue of creative incentives. 
shadow of Worth, those who do business with copyrights must now alter their commercial behavior-under either the federal copyright standard or the community property standard. ${ }^{14}$

\section{Copyright and Community Property: The Background of Worth}

The Worth decision purports to find no inconsistency in its application of federal copyright law and California community property law. Instead, Worth provides a messy union of two bodies of law with distinct historical justifications and objectives. This union hinders the goals of copyright law without substantially enhancing the goals of community property law.

\section{Copyright}

Federal copyright law is based upon the constitutional grant "[t]o promote the Progress of Science and useful Arts, by securing for limited Times to Authors and Inventors the exclusive Right to their respective Writings and Discoveries."15 Federal copyright law grants protection to authors against infringement of their works for set periods of time. ${ }^{16}$ The requirements for copyright protection are that a work be original, i.e., not copied, and fixed in a tangible medium of expression. ${ }^{17} \mathrm{~A}$ "tangible medium of expression" is any form from which a work can be "perceived, reproduced, or otherwise communicated, either directly or with the aid of a machine or device." 18 Works eligible

14. See Perlstein, Copyright as Community Property: Questions About Worth Are More than Merely Trivial, 9 ENT. L. REP. 3 (Apr. 1988).

Worth also raises choice of law problems, both domestically and internationally. In the international setting, the Worth ruling raises complex problems. In international motion-picture distribution, for example, foreign distributors often are required to present documentation showing proper chain of title-which usually requires the signatures of all copyright owners--before they can distribute a picture, and often before an infringement suit can be brought. See Geller, International Copyright: An Introduction, in 1 INTERNATIONAL COPYRIGHT LAW AND PRACTICE INT-1, \& 6, at INT-202 to INT-203 (M. Nimmer \& P. Geller eds. 1990). If only the signatures of authors were present in the documents (which is likely for all deals that predate Worth), accused international video pirates, for example, could move to have infringement suits dismissed on the ground that all the required signatures of the copyright owners were not included in the chain of title documents. This could occur for any American work, even if it did not originate in California, and even if none of the authors had ever been married (here the issue would become proving the author was not covered by California law, or not married). The Worth decision thus has the effect of increasing costs for international film distribution, making recourse against pirates and other infringers more difficult to obtain, and creating international choice of law issues for foreign and domestic courts.

15. U.S. CONST. art. I, \& 8, cl. 8. For historical background on United States copyright law, see generally R. BOWKER, COPYRIGHT: ITS HISTORY AND ITS LAW 1-41 (1912), and G. CURTIS, TREATISE ON THE LAW OF COPYRIGHT 26-82 (1847).

16. The Act grants protection for the author's life plus fifty years. 17 U.S.C. $\S 302$ (a) (1988).

17. 17 U.S.C. $\$ 102($ a) (1988). Federal copyright law protects only original expression, not ideas. See id. $\S 102(\mathrm{~b})$. Copyright does not bar another author who independently creates a work with the same idea as a copyrighted work from exploiting that work. Copyright infringement actions involve proving that a protected work has been copied. In practice, this can be done by showing access to the protected work by the alleged infringer and substantial similarity between the works. See, e.g., Ferguson v. National Broadcasting Co., 584 F.2d 111 (5th Cir. 1978).

18. 17 U.S.C. $\S 102(a)$ (1988). 
for copyright protection include literary works, computer programs, music, motion pictures, paintings, sculpture, ${ }^{19}$ and derivative works. ${ }^{20}$

The traditional theoretical justification for copyright protection is that society grants artists the right to exclude others from copying their works for a limited time in order to provide economic incentives to create. ${ }^{21}$ These incentives assure a continuing supply of creations that society wants. Copyright protection is granted primarily for the benefit of the public, not just the individual author. ${ }^{22}$ Authors are protected for an arbitrary length of time because society has decided to encourage them to create things like books and music.

Part of the bundle of rights granted by federal copyright law is the right to control the commercial exploitation of copyrighted works. Subject to some specific limitations enunciated in the $\mathrm{Act}^{23}$ the owner of a copyright has the exclusive right to control the production and commercial exploitation of copies or recordings of the work, production of derivative works, and public performance and/or display of the work. ${ }^{24}$ Copyright vests initially with the author of a work; ${ }^{25}$ however, the author and any subsequent owner can sell or transfer in part or in whole her rights in copyrighted works. ${ }^{26}$ By virtue of her exclusive right to copy her own works, an author has the corollary right to refrain from commercially exploiting her works if she so desires. ${ }^{27}$

Federal copyright law allows for joint ownership ${ }^{28}$ both directly by authors and indirectly by others. Joint ownership of a copyright occurs directly when a "joint work" is created by two or more authors, ${ }^{29}$ for example, by co-writing a book or a piece of music. Joint ownership also occurs when ownership of the

19. Id.

20. Id. § 103. The Act defines a "derivative work" as "a work based upon one or more preexisting works, [in any form] in which a work may be recast, transformed, or adapted." Id. $\S 101$.

21. Another theoretical justification for intellectual property protection is that intellectual property should be treated just like tangible property. The creator makes it, and therefore, the creator should be able to control what happens to it. See Easterbrook, Intellectual Property is Still Property, 13 HARV. J.L. \& PUB. POL'Y 108 (1990).

22. A. LATMAN, R. GORMAN \& J. GINSBURG, COPYRIGHT FOR THE NINETIES 14-15 (3d ed. 1989).

23. Limitations on exclusive rights include "fair use," which allows reproduction for "criticism, comment, news reporting, teaching, . . . scholarship, or research," 17 U.S.C. $\$ 107$ (1988), and reproduction of single copies for security purposes by libraries and archives, Id. $\S 108$ (a)-(b).

24. Performance and display of a work are both defined by the Act, id. $\S 101$, as are performance and display rights. $I d$. § 106.

25. Id. $\S 201$ (a). This discussion applies with equal force to the authors of joint works.

26. Id. § 201(d)(1).

27. Since 1965, J.D. Salinger has chosen not to exploit his writing commercially, although he is rumored to be an active writer. Because his rights as an author vest when his writing is rendered in a tangible medium, i.e., as soon as it is written down, these unpublished works are protected by the Act. Because he has the exclusive right to publish his writing under the Act, his right not to be published also is protected under the Act. See Salinger v. Random House, Inc., 811 F.2d 90 (2d Cir.), cert. denied, 108 S. Ct. 213 (1987). Under Worth, were Salinger a California resident, his wife would own half of the copyright on each unpublished work produced during their marriage. As a co-owner, she could publish his writings independently, or license the creation of derivative works, such as movies or television programs based on his writings, without his consent, despite his express desire not to publish them.

28. 17 U.S.C. $\S 201$ (a) (1988).

29. Id. Section 101 defines a joint work as "a work prepared by two or more authors with the intention that their contributions be merged into inseparable or interdependent parts of a unitary whole." 
copyright is transferred from an existing owner to two or more parties when they purchase the copyright together, or it can occur by operation of law..$^{30}$ The traditional transfers of copyright by operation of law involve copyrights passed in bankruptcy and those passed by intestacy upon death of the owner. ${ }^{31}$

These transfers can be of the entire copyright or of certain rights only. ${ }^{32}$ Any given work can therefore have many owners: some owning certain rights exclusively, some owning other rights nonexclusively. Some rights can be owned jointly, while others are owned by individuals. An owner whose rights result from a transfer is entitled to the same protection as an owner whose rights result from original authorship. ${ }^{33}$

Where a copyright is jointly owned, an exclusive license requires the approval of all owners. ${ }^{34}$ The exclusive rights granted to a work often are transferred by sale as separate rights to different buyers. ${ }^{35}$ All of these subsequent owners can resell their rights, or transfer their rights upon death or bankruptcy. As a result of these ordinary business transfers, the original bundle of all exclusive rights attaching to a copyrighted work and held by its author or authors is broken down into separate rights owned by different entities. Thus, it is common for the ownership of the component rights of a copyright to be divided up, either by sale or by operation of law.

Any joint owner can transfer rights in the work on a nonexclusive basis without the consent of the other owner or owners. ${ }^{36}$ Thus, for example, a joint author of a book could sell the nonexclusive right to adapt the book into a musical without the consent of the other author, as long as the other author could also nonexclusively license the book for another musical. While all of these rights can be licensed nonexclusively in theory, certain kinds of lucrative rights are virtually impossible to license nonexclusively in practice because of the nature of some kinds of copyrighted works. ${ }^{37}$ Movie producers generally do not want to invest millions in making a movie if they face competition from another nonexclusive licensee of the movie rights to a given novel. ${ }^{38}$ Thus,

30. Id. § 201(d)(1) (1988). Copyrights may also be transferred by will. Id.

31. Id.

32. Id. \& 201(d).

33. Id. $\$ 201(\mathrm{~d})(2)$.

34. 1 M. NIMMER \& D. NIMMER, NQMMER ON COPYRIGHT §§ 6.10-.11 (1990).

35. For example, a fully exploited novel would typically result in transfers of the hardback publication rights to one publisher, and the paperback rights to another, a production company or producer would buy the motion picture and television rights; a merchandiser would get the rights to a derivative board game; a composer might buy the rights to produce a derivative musical; and a playwright could acquire the rights to a derivative stage play.

36. 1 M. NMMMER \& D. NIMMER, supra note $34, \S 6.11$.

37. In effect, execution by one co-owner of a nonexclusive license for motion picture rights destroys the ability of the other owner(s) to sell other nonexclusive motion picture licenses. Id. §6.10[A].

38. Occasionally, two movies based on the same story will be made within a relatively short time period. For example, Dangerous Liaisons (Warner Brothers 1988) and Valmont (Orion 1989) are both based on the same novel, Les Liaisons Dangereuses, by Choderlos de Laclos, first published in 1782, and now in the public domain. The risks for a producer in investing in a nonexclusive work include the danger that the movie-going public will decide not to see a movie it perceives as just an imitation of something already 
the grant of a nonexclusive license by a co-owner can have a significant negative impact on the economic return generated by a particular work. ${ }^{39}$

A goal of federal copyright law is the imposition and maintenance of a single national standard to determine the basis for and validity of copyright transfers. ${ }^{40}$ Copyrighted works, by their nature, are goods produced for the purpose of commercial exchange on a national and international basis. Having a single national standard gives all authors the same rights and protections, and allows copyrighted works to be exchanged efficiently.

\section{Community Property}

The goals of copyright law include providing creative incentives and establishing a single national standard for copyright exchange; in contrast, the main goal of community property law is to recognize in economic terms the contribution of nonbreadwinner spouses. ${ }^{41}$ While specific statutes vary from state to state, ${ }^{42}$ their common theme is that both partners contribute to the success of the marital community, and therefore are equal partners, each owning a half interest in all assets acquired during a marriage. ${ }^{43}$ Community property systems recognize that the contribution of one spouse to raising children and maintaining a home has the dual effect of limiting that spouse's earning capacity while increasing the working spouse's earning capacity. ${ }^{44}$ To address this common situation, community property uses the method of treating the two spouses equally in terms of assets acquired during a marriage, regardless of who actually earned them. Upon dissolution of a marriage, community property law prevents the breadwinner spouse from taking out of a marriage income and assets otherwise attributable to her efforts only.

Community property systems-including California's-characterize all property as either separate property or community property. ${ }^{45}$ Separate property typically is anything an individual owned prior to entering a marriage, income received from separate property, and property received by descent,

seen. Obviously, the movie that gets released first in this instance has a commercial advantage.

39. The nonexclusive license would presumably be sold for less than an exclusive license could have been. In all likelihood, not enough nonexclusive licenses could be sold such that their aggregate return would equal the return of one exclusive license.

40. See 1 M. NMMMER \& D. NIMMER, supra note 34, § 1.01[A].

41. Vaughn, The Policy of Community Property and Inter-spousal Transactions, 19 BAYLOR L. REV. 20, 31-41 (1967).

42. Eight states, primarily those in the Southwest with a French or Spanish tradition, treat marital property as community property. See supra note 2.

43. See W. DE FUNIAK \& M. VAUGHN, PRINCIPLES OF COMMUNTTY PROPERTY \& 105, at 262 (1971); Vaughn, supra note 41 , at 26.

44. Vaughn, supra note 41 , at $31-41$.

45. See W. DE FUNIAK \& M. VAUGHN, supra note 43 , § 1, at 2; see also 11 B. WITKIN, supra note $2, \S 3$, at 377 . 
devise, or gift during the marriage. ${ }^{46}$ Income and property acquired during a marriage that does not fit the statutory definition of separate property is by definition community property, belonging to both partners, regardless of who earned the income, or who purchased or holds title to the property. ${ }^{47}$

In California, community personal property, which includes copyrights, ${ }^{48}$ may be transferred by either spouse as long as it is not given away and valuable consideration is received in return. ${ }^{49}$ Proceeds from the transfer of community property are also community property ${ }^{50}$ Each spouse is required to act in good faith with respect to the "management and control" of community property. ${ }^{51}$ In addition, one spouse "who is operating or managing a business or an interest in a business that is all or substantially all community personal property has the primary management and control of the business or interest." "Primary management and control" gives the managing spouse the power to make all decisions related to that business, subject only to the good faith requirement and to a duty to give the nonmanaging spouse prior written notice. ${ }^{53}$

46. See, e.g., CAL. CV. CODE $\S \S 5107-5108$ (West 1983). Rents and profits from separate property are also separate property in California. Id. In California separate property may be conveyed by the spouse who owns it, without the consent of the other spouse. Id. When the spouses move to different residences, income of the separated spouses and of the children living with the respective spouses is separate property from the date of the separation. Id. § 5118. See generally W. MCCLANAHAN, supra note $2, \S 4: 10$.

47. See W. DE FUNIAK \& M. VAUGHN, supra note $43, \S 66$, at 143; see also, CAL. CIV. CODE $\S 5105$ (West 1983). See generally W. MCCLANAHAN, supra note $2, \S 4: 13$. California defines community property as all property, real (when situated within the state) or personal (wherever situated), other than separate property as defined in the statute. CAL. CIV. CODE $§ 5110$ (West 1983 \& Supp. 1990). Where community property and separate property are commingled or the source is uncertain, there is a strong presumption in California in favor of characterizing the property as community property. Estate of Luke v. Vahldieck, 194 Cal. App. 3d 1006, 1018, 240 Cal. Rptr. 84, 91 (1987); In re Marriage of Marsden, 130 Cal. App. 3d 426, 441, $181 \mathrm{Cal}$. Rptr. 910, 918 (1982). In addition to income earned by the partners during a marriage, community property can include other forms of wealth and unearned income, such as damages from personal injuries to one spouse and pensions. See W. MCCLANAHAN, supra note 2, § 6:27 (personal injury damages as community property generally), $\$ \S 6: 21-: 23$ (pensions as community property generally); $\mathrm{B}$. WmKR, supra note $2, \S 25$ (personal injury damages as community property in California).

48. Property in California is characterized as either real or personal. Real property is immovable; it is specifically defined as land and things related to land (fixtures, crops, etc.). Personal property is everything that is not real property, including rights to intangible assets like goodwill and products of an author. CAL. CIV. CODE $\S \S 655,657-660,663$ (West 1982).

49. CAL. CIV. CODE $\$ \S 5125$ (a)-(b) (West 1983 \& Supp. 1990). In contrast, community real property may not be transferred without the consent of both spouses. Id. $\S 5127$.

50. A change in the form of community property does not affect its character as community property. W. BASSETT, CALIFORNIA COMMUNITY PROPERTY HANDBOOK § 1.01[C] (1989).

51. CAL. Crv. CODE $\S 5125(\mathrm{e})$ (West 1983 \& Supp. 1990).

52. Id. $\S 5125(\mathrm{~d})$.

53. Id. $\S 5125$ (d)-(e) It is unclear whether the business of producing copyrighted works for sale would come under the primary management and control provision. One commentator has suggested that the problems created by Worth could be alleviated by considering an author the primary manager of a business. Perlstein, supra note 14, at 6 . This invites a distinction, however, between successful authors who have been paid regularly for their works and those who have sold little or nothing. Unless a part-time author is considered the primary manager of a business, only established authors would be able to control their works. 


\section{Copyright as Community Property: The Worth Rationale}

Although scholars had speculated that copyright ownership might be treated as community property ${ }^{54}$ no court did so specifically until the Worth case. ${ }^{55}$ Because Frederick Worth "conceived, wrote and published the trivia books during the marriage," the court reasoned, "the conclusion is inescapable that such literary works constituted community property." If the underlying work is community property, then ownership of the copyright is also community property. ${ }^{57}$

The court rejected Frederick Worth's argument for federal preemption of California community property law under the Copyright $\mathrm{Act}^{58}$ by combining the operation-of-law mechanism of federal copyright law with the substance of California community property law. The standard for federal preemption of state family law is enunciated in another California community property case, Hisquierdo v. Hisquierdo:59 "State family and family-property law must do 'major damage' to 'clear and substantial' federal interests before the supremacy clause will demand that state law be overridden." 60 The Worth court avoided federal preemption by reasoning that although rights initially vest in the author spouse as soon as the work is rendered in a tangible medium of expression, ${ }^{61}$ because the Act provides for transfer of copyright by "operation of law,"62

54. See, e.g., Patry, Copyright and Community Property: The Question of Preemption, 28 BuLL. COPYRIGHT SOC'Y 237 (1981).

55. Nimmer, Copyright Ownership by the Marital Community: Evaluating Worth, 36 UCLA L. REV. 383,385 (1988).

56. In re Marriage of Worth, 195 Cal. App. 3d 768, 773, 241 Cal. Rptr. 135, 137.

57. Id. at 774, 241 Cal. Rptr. at 137.

58. Id. at 776, 241 Cal. Rptr. at 139. Under the supremacy clause, U.S. CoNST. art. VI, cl. 2, a state law falls when it conflicts with federal law.

59. 439 U.S. 572 (1979) (Railroad Retirement Act benefits are property of retired spouse alone) (overruling California Supreme Court). Although Congress subsequently expressed a policy contrary to the specific holding of Hisquierdo, see 45 U.S.C. $\$ 231 \mathrm{~m}(\mathrm{~b})(2)(1988)$, that case still articulates the Supreme Court standard for assessing community property preemption under the supremacy clause.

60. 439 U.S. at 581 (citing United States v. Yazell, 382 U.S. 341, 352 (1966)).

61. 195 Cal. App. 3d at 777, 241 Cal. Rptr. at 139.

62. Id. at 774, $241 \mathrm{Cal}$. Rptr. at 137. The Worth court's reasoning assumes that there is no relevant difference between a traditional copyright transfer by operation of law, and the transfer in Worth, which was by operation of California marital law. Interestingly, the court fails to mention Section 201(e) of the Act, which reads:

When an individual author's ownership of a copyright . . . has not previously been transferred voluntarily by that individual author, no action by any governmental body ... purporting to seize, expropriate, transfer, or exercise rights of ownership with respect to the copyright . . . shall be given effect under this title except as provided under Title 11.

17 U.S.C. $\$ 201$ (e). As Title 11 covers bankruptcy, transfers by operation of bankruptcy law do not require an author's consent. With the exception of involuntary bankruptcy, then, Section 201 (e) essentially prohibits transfers by operation of law where the author has not consented, or consent cannot be implied. See Nimmer, supra note 55, at 408-09. In cases where community property law was preempted by federal law, Congress was found to have spoken with "force and clarity" to the effect that the benefit in question be considered the separate property of the spouse upon whom it was conferred. See Wissner v. Wissner 338 U.S. 655, 658 (1950) (National Service Life Insurance policy is property of named beneficiary alone). Thus, unless marriage is viewed as implying consent by the author to the transfer of a half interest in the copyrighted works produced during the marriage, the only way to reach the Worth result is to hold that Section 201(e) 
California was not precluded from transferring half ownership to the nonauthor spouse by operation of California marital law. Therefore, the Worth court found that treating copyright ownership as community property was not inconsistent with the $\mathrm{Act}^{63}$ and thus there was no federal preemption of this application of California community property law. ${ }^{64}$

\section{OWNERSHIP OF A COPYRIGHT SHOULD NOT BE TREATED AS COMMUNITY PROPERTY}

Given the policy of providing incentives to create, the specific market characteristics of copyright, and the special nature of authorship, copyright ownership ought not be treated as community property. The Worth court's treatment of copyright ownership as community property hinders the goals of copyright without substantially aiding those of community property law.

Treating copyright as community property dilutes authors" incentives to create by denying authors full control over the decision of how best to exploit their works. The following hypothetical ${ }^{65}$ demonstrates how Worth permits such a result. Suppose that our author writes carefully crafted short stories, perhaps publishing one or two a year. Her reputation grows steadily in literary circles, but is still in its infancy, and she is virtually unknown among the general public. After a bitter divorce, the author receives two competing offers for exclusive movie deals on the same story, a subtle character piece about a grandmother-granddaughter relationship that was written during the marriage and is our author's best work to date. One offer is from a major studio for $\$ 200,000$; the production executives love the story, but want to change the ending to make it less sad, and to add a chase sequence with the grandmother driving a stolen car. The other offer is for $\$ 15,000$, from a small production company known for making quality, lower budget art films of the caliber of A Room with a View. ${ }^{66}$ Our author wants to accept the $\$ 15,000$ offer because

does not speak with "force and clarity" in favor of preemption of California community property law. This is hardly a straightforward reading of the express language of the statute. For an analysis of Section 201(e), see Nimmer, supra note 55, at 407-09.

63. 195 Cal. App. 3d at 777, 241 Cal. Rptr. at 139.

64. The court also rejected Frederick Worth's argument in favor of federal preemption under section 301 of the Act. Id. Section 301 provides that no state shall grant rights equivalent to those granted by section 106 of the Act. 17 U.S.C. 301 (1988). The court stated that "[r]ights of ownership and division of marital property are in no way equivalent to rights within the scope of copyright under the federal Copyright Act." 195 Cal. App. 3d at 778, 241 Cal. Rptr. at 140.

65. To date no reported cases have addressed the impact of Worth. In divorce cases the trend in recent years has been toward privately negotiated settlement, worked out against the backdrop of existing divorce law. See Mnookin \& Komhauser, Bargaining in the Shadow of the Law: The Case of Divorce, 88 YALE L.J. 950 (1979); cf. Mnookin, Divorce Bargaining: The Limits on Private Ordering, 18 U. MICH. J.L. REFORM 1015 (1985). The question here is not whether cases involving Worth actually get litigated. Rather, the questions are (1) in what manner we want legal rules to structure the bargaining positions of married authors and their spouses, and (2) what burdens we want placed on buyers and sellers of intellectual creations.

66. Cinecom Int'1 Films 1986. 
she believes that the artistic integrity of the story will be better maintained by the small company. In addition, the author feels an appropriate production is essential, as this will be the first national attention her work will receive. Although the short term monetary gain is far less, our author feels that choosing the smaller production company is better for her long term reputation.

Because an author should be free to make this critical decision regarding the presentation of her work, copyright ownership should not be treated as community property. After Worth, an embittered nonauthor spouse could either attempt independently to license the story to the big studio first if the community property standard was applied, or force some sort of settlement if the copyright standard was used. After a divorce, the nonauthor spouse's interest is in maximizing the return on community property works, while the author's interest may be in nonpecuniary gains such as reputation and career longevity. Depending upon the transfer standard applied, Worth could force an artist to sell her works to the highest bidder in order to obtain the nonauthor spouse's approval for an exclusive sale, or to race to conclude a less attractive deal in order to be first in time. By thus impeding free disposition of created works by authors, Worth reduces incentives to create, and thereby thwarts the purposes of federal copyright law. ${ }^{67}$

The particular market for copyrighted works magnifies the effect of Worth on authors' incentives to create. The Worth court failed to recognize that treating copyright ownership as community property yields adverse consequences distinct from those arising from treating other sorts of property as community property. Copyrighted works are bought and sold in a different market than other types of property. A distinctive market-characteristic of copyright is that some rights among the total bundle of ownership rights may be, and frequently are, retained by the author even after a primary deal is concluded. Because the markets for different kinds of copyrighted works vary, some rights often remain unsold. This might be because the initial work does not lend itself to every sort of derivative treatment: philosophy textbooks are not normally adapted into musicals, for example. It may be impossible to predict when or whether many derivative rights will be sold because the commercial value of either the author or the work is unproven: movie rights to early novels and stories are often sold long after initial publication, when a subsequent work becomes a best seller, for instance, or when the author comes into vogue.

The sale of a copyright is evidenced only by the contract of sale. ${ }^{68}$ Thus, years later, when retained rights are sold, Worth requires buyers to determine if the author was married at the time the work was produced, and to locate the

67. One could argue that Worth does not prevent an author from controlling her work, but simply makes it more expensive for the author spouse to gain control of her work. Even if an author could always achieve control under Worth (which is not at all clear), the increased cost still yields a disincentive to create.

68. The U.S. Copyright office does not record transfers of copyrights. 
nonauthor spouse either to get approval or to find out if an independent nonexclusive license exists. Because an author cannot always know if her spouse or former spouse has executed a prior license, giving nonauthor spouses control over a copyright effectively clouds the title to the work. With transfers of land, on the other hand, title is recorded at a municipal office, so a buyer can check if the seller has the power to sell the land; in the case of the sale of other tangible assets, the sold object is physically handed over to the buyer, so the asset will be gone if one spouse sells it. Thus, the effect of treating copyright ownership as community property differs from the effect of such treatment for other forms of property, because of the particular retained-rights aspect of copyright ownership and the lack of systemized recording of transfers.

Treating copyright ownership as community property is also different than treating tangible property as community property because the way one copyrighted work is exploited can affect the future marketability of other works created by the author spouse. If a nonauthor spouse markets a community property work in a manner contrary to the marketing posture taken by the author spouse, the nonauthor spouse's activities can affect the success of the author spouse's marketing efforts. For example, if a painter is building a reputation as a serious artist, and the painter's spouse markets coffee mugs and t-shirts emblazoned with one of the painter's community property works, the painter may have difficulty selling serious work in the future. When property is divided upon divorce, post-separation works are considered separate property. ${ }^{69}$ Thus, if the painter's spouse's sale of coffee mugs increases the profitability of the painter's community property works to the detriment of the painter's other works, the painter's spouse effectively gains access to the painter's separate property. ${ }^{70}$ In addition, the sale of a nonexclusive license by the nonauthor spouse can detrimentally affect the price the author can obtain for the remaining rights.

These adverse consequences do not occur when other forms of property are treated as community property. Other assets owned by a married couple are generally sold once, with all rights as part of the package. The sale of a particular piece of community property does not typically affect the ability to sell other like pieces, nor does it affect the ability of the spouse to sell like separate property. The distinctive features of the market for copyrighted works make authorial control a crucial component of the incentives to create. ${ }^{71}$

69. CAL. CIV. CODE $\S 5118$ (West 1983).

70. This reasoning echoes the California graduate degree cases. These cases hold that, because post-dissolution earnings are defined by statute as separate property, $i d$., the value of the education that made those earnings possible could not be considered a community asset. See, e.g., In re Marriage of Aufmuth, 89 Cal. App. 3d 446, 460-61, 152 Cal. Rptr. 668, 677-78 (1979).

71. If the market for copyrighted works functioned differently, Worth would not have the same impact on authors' incentives. In the case of works-for-hire, for example, Worth has no effect on incentives to create. There, the copyright is owned by the person or company that hired the author. 17 U.S.C. $\S \S 101$, 201(b) (1988). Thus, the author enters the arrangement knowing that the copyright owner can dispose of the work as she sees fit. In the work-for-hire situation, the specific contract fee is all the author will ever 
In addition to the policy of providing incentives to create, the nature of copyrighted works, as opposed to other forms of property, suggests that such works ought not be treated as community property. Simply put, there is something special about authorship that demands we give creators ultimate control over the marketing and disposition of their works (until the author sells the copyright, at which time, of course, she renounces such control). This argument is in the spirit of the moral rights theory of copyright, not traditionally used to justify copyright protection in the United States, ${ }^{72}$ but recognized elsewhere. ${ }^{73}$ As discussed previously, federal copyright protection is not premised on the natural right of an author to control her creation, but upon utilitarian grounds. However, by encouraging the creation of copyrighted works, federal copyright law implicitly recognizes the intrinsic worth-not just the social value-of what authors do. While federal copyright law may not give authors control over the disposition of their works simply because they created them, an argument in favor of extending authors this control on moral grounds is consistent with the utilitarian policies and goals of copyright law. ${ }^{74}$

\section{WORTh FAILS UNDER COMmerce Clause ANALYsis}

Apart from the question of whether copyright should be community property is that of whether treating copyright as community property passes constitutional muster. ${ }^{75}$ Based on Supreme Court commerce clause jurispru-

receive for the work. Worth would affect the incentives of individuals who hire authors to create works, as their copyright ownership would be community property. Thus, to the extent that individuals invest in the creation of copyrighted works by means of works-for-hire, Worth would have an effect on that investment. In situations where works-for-hire are owned by publicly held companies, Worth would have no effect whatsoever. Thus, one effect of Worth may be to encourage corporate-owned work-for-hire at the expense of individual creation or work-for-hire ownership.

72. "Moral rights" are personal rights of the author, distinct from economic rights, such as the author's right of paternity (the right to claim authorship of a work) and the right of integrity (the right to prevent the destruction or defacement of a work). In 1990 Congress passed an amendment to the Act recognizing moral rights for visual artists. Visual Artists Rights Act of 1990, Pub. L. No. 101-650, 104 Stat. 5089, 5127 (1990).

73. France, for example, recognizes "moral rights." See Plaisant, France, in 1 INTERNATIONAL COPYRIGHT LAW AND PRACTICE, supra note 14, FRA-1, § 7, at FRA-12.

74. Richard Epstein argues that, while differences remain, utilitarianism can justify the assumptions of natural rights theories. Epstein, The Utilitarian Foundations of Natural Law, 12 HARV. J.L. \& PUB. POL'Y 713 (1989).

75. There are other ways for the practical problems of Worth to be alleviated. The California courts could clarify which transfer standard applies. The California courts could also, as one commentator has suggested, presume consent between the spouses granting sole authority to the author spouse over ownership decisions. Nimmer, supra note 55, at 414 . Although this method would solve the Worth problem if a judge decided to use it, another judge could just as easily reject it.

State statutory solutions also have been suggested. See id. at 413 . Congress could amend the ownership language of the Act to indicate that ownership of a copyright is the separate property of the author. Such a statute would supersede the Worth holding in California, and prevent other community property states from following California's lead.

Individual parties can prevent problems in future deals with careful contract drafting. See Perlstein, supra note 14, at 6. Premarital agreements-or, for pre-existing contracts, documents either from transferors affirming their unmarried status at all relevant times, or from spouses and former spouses agreeing to the 
dence, the Worth court's application of California community property law impermissibly interferes with interstate transfers of copyright. Supreme Court cases have held state laws to be preempted under the commerce clause where the state regulations result in impermissible interference in interstate matters, even though (1) the state may have a genuine interest in the area it seeks to regulate, and (2) federal regulation in the area of the state law does not specifically preempt the state regulation.

The Supreme Court currently uses two different approaches when reviewing commerce clause challenges to state regulations. As the Court explained in one of its most recent commerce clause cases, Brown-Forman Distillers Corp. $v$. New York State Liquor Authority: ${ }^{76}$

When a state statute directly regulates or discriminates against interstate commerce, or when its effect is to favor in-state economic interests over out-of-state interests, we have generally struck down the statute without further inquiry. When, however, a statute has only indirect effects on interstate commerce and regulates evenhandedly, we have examined whether the State's interest is legitimate and whether the burden on interstate commerce clearly exceeds the local benefits. ... In either situation the critical consideration is the overall effect of the statute on both local and interstate activity. ${ }^{77}$

The Court goes on to apply the first approach, usually called the per se test. ${ }^{78}$

\section{A. Brown-Forman and the Per Se Test}

In Brown-Forman, the Supreme Court declared a New York price regulation statute unconstitutional on its face under the commerce clause. The New York statute at issue had required all liquor producers selling to wholesalers in New York to affirm that their New York prices would be as low as their prices in other states for the following month. The Court reasoned that because the statute prevented a producer from reducing its prices in another state after New York State's prices were set for the month, New York was in effect reaching out to regulate business within other states: "New York has 'project[ed] its legislation' into other States, and directly regulated commerce therein ...."79 The Court held the statute unconstitutional on its face even though it was

prior transfer-would resolve the problems, where these documents could be obtained. While it is difficult to estimate how much Worth will cost individuals in general, it is clear Worth increases costs for everyone concerned. Worth may produce a net gain for nonauthor spouses, but costs as a whole will be likely to increase because of the addition of something else to litigate.

76. 476 U.S. 573 (1986).

77. Id. at $\mathbf{5 7 9}$ (citations omitted). The Court notes: "We have also recognized that there is no clear line separating the category of state regulation that is virtually per se invalid under the Commerce Clause, and the category subject to the Pike v. Bruce Church balancing approach." Id; see infra Section MI.B.

78. 476 U.S. at $579-80$.

79. Id. at 584 (citation omitted). 
directed only at internal New York pricing because "the 'practical effect' of the law [was] to control liquor prices in other States." ${ }^{80}$ This regulatory effect rendered the statute unconstitutional despite New York's legitimate interest in securing low prices for New York consumers.

The California community property statute at issue in Worth has essentially the same flaws that the Brown-Forman Court found fatal for the New York statute. By declaring a community property interest in copyright ownership, California forces citizens of other states, doing business with other non-California residents, to alter their method of doing business at substantial cost in order to protect themselves from the regulatory effect of the statute as interpreted in Worth. The community property statute also burdens nonCalifornia citizens who have co-authored works with California residents and wish to do business involving their works with other non-California residents. Moreover, buyers dealing with Californians may have to pay more to secure the nonauthor spouse's approval; therefore, California essentially makes buyers pay a premium to California nonauthor spouses. When one state treats copyright ownership as community property, those whose business includes the transfer of copyrights must take precautions in drafting their contracts to try to avoid the potential problems created by that treatment. ${ }^{81}$ For example, if both spouses jointly sign an exclusive licensing agreement, the transfer would be valid regardless of whether the community property or the copyright transfer standard applied. Thus, those who engage in businesses involving copyrights, whether within California or without, now bear the burden of determining the domicile of the apparent copyright owner, or else bear the substantial cost of procuring nonauthor spouses' approval for every transfer. ${ }^{82}$

As was true in Brown-Forman, the fact that the statute in Worth is aimed explicitly only at California domiciliaries should not protect the statute from a commerce clause challenge. Although Worth has a less direct effect on interstate commerce than the price affirmation statute in Brown-Forman, the "practical effect" of treating copyright ownership as community property is to "project" ${ }^{83}$ California property law into other states by reaching out to regulate copyright transfers between citizens of other states. Worth forces not only

80. Id. at 583 (citation omitted).

81. Existing exclusive deals would be valid if the community property standard is applied because either spouse could make an exclusive transfer. Existing exclusive deals may be invalid if the copyright standard is applied because approval of both spouses is required.

82. One's domicile can be changed by moving to a new state with the intent to reside and remain there indefinitely. See Smith v. Smith, 45 Cal. 2d 235, 239, 288 P.2d 497, 499 (1955); Johnson v. Johnson, 245 Cal. App. 2d 40, 44, 53 Cal. Rptr. 567, 570 (1966); Estate of Brace, 180 Cal. App. 2d 797, 802, 4 Cal. Rptr. 683,687 (1960). Any person who seeks to purchase copyrights, whether in California or not, must verify that the party from whom she is purchasing the rights is not a California domiciliary. If the transferor is a California domiciliary, the purchaser must, under the community property standard, verify that a nonauthor spouse has not executed a prior conflicting license, or, under the copyright standard, procure the nonauthor spouse's approval for the transfer.

83. Brown-Forman Distillers Corp. v. New York State Liquor Auth., 476 U.S. 573, 583-84 (1986) (citation omitted). 
Californians, but also-and more importantly for commerce clause purposes-non-Californians to investigate the author's domicile, prior licenses by the nonauthor spouse, and the related contract revision, all of which involve additional expense. ${ }^{84}$ Such treatment is therefore invalid under the commerce clause per se test used in Brown-Forman.

In addition, the Court has characterized Brown-Forman as an example of a case where it invalidated a statute that "adversely affect[ed] interstate commerce by subjecting activities to inconsistent regulation." 85 Statutes cause impermissibly inconsistent regulation under the commerce clause where their subjects "are in their nature national, or admit only of one uniform system, or plan of regulation." ${ }^{86}$ The regulation of copyright ownership, promulgated under a Constitutional grant, and governed by a federal statute which specifically calls for preemption of inconsistent state laws, ${ }^{87}$ is an area that "admit[s] only of one uniform system." Therefore, treating copyright as community property is impermissible under the Brown-Forman commerce clause test. Finally, it makes no difference that California's community property statute has traditionally been characterized as marital law. Because treating copyright ownership as community property effectively regulates commercial behavior by favoring in-state nonauthor spouses over out-of-state interests, such treatment fails the per se test. The triggering condition for the statute is the state of marriage, but the subject matter-marital property-is entirely economic.

\section{B. Pike and the Balancing Test}

The second approach taken by the Supreme Court when reviewing commerce clause challenges to state regulations is the balancing test, best formulated in Pike v. Bruce Church, Inc. ${ }^{88}$ The balancing test requires that burdens placed on interstate commerce be weighed against the benefits accruing to instate parties. As the Court explained in Pike:

Where the statute regulates evenhandedly to effectuate a legitimate local public interest, and its effects on interstate commerce are only incidental, it will be upheld unless the burden imposed on such commerce is clearly excessive in relation to the putative local benefits... [T] extent of the burden that will be tolerated will of course depend on the

84. Under Worth, California domiciliaries would face the same burdens as non-Californians, but the fact that some in-state parties are burdened in the same way as out-of-state parties has been held irrelevant in assessing a statute's validity under the commerce clause. See Dean Milk v. Madison, 340 U.S. 349, 354, n.4. (1951); see infra note 93 and accompanying text. As long as California law reaches out to interstate transactions involving non-California parties, the law must be permissible under the commerce clause.

85. CTS Corp. v. Dynamics Corp. of America, 481 U.S. 69, 88 (1987) (citation omitted).

86. Id. at 88-89 (citing Cooley v. Board of Wardens, 53 U.S. (12 How.) 299, 319 (1852)).

87. 17 U.S.C. 301 (1988). Even if the Worth court is correct, and there is no federal preemption under section 301, see supra notes 58-64 and accompanying text, section 301 still evidences Congressional recognition of the need for a consistent body of copyright regulation nationwide.

88. 397 U.S. 137 (1970). 
nature of the local interest involved, and on whether it could be promoted as well with a lesser impact on interstate activities. ${ }^{89}$

Under Pike a state statute that survives the per se test will still be struck down if the indirect burdens imposed on interstate commerce by the statute outweigh the legitimate state interest. The balancing test examines the actual impact of the challenged law, and whether the same interest could be adequately promoted in another, less burdensome way.

The Arizona statute at issue in Pike required that all cantaloupes grown in Arizona be packed in Arizona in specific standard containers which identified the goods as being from Arizona before their shipment out of state. Bruce Church, Inc. grew high quality cantaloupes in Arizona which it shipped in bulk across the nearby state line into California for packing at its existing plant. Arizona had an interest in promoting Arizona produce by guaranteeing that Bruce Church's high quality cantaloupes would be accurately identified as Arizona produce. This regulation, were it enforced, would have forced Bruce Church to build a new packing facility inside Arizona so that the cantaloupes could be labeled before they were shipped. By balancing these interests the Court concluded that "[the commerce clause] cannot permit a State to require a person to go into a local packing business solely for the sake of enhancing the reputation of other producers within its borders." held, could not force Bruce Church to change its national business methods at substantial expense for the sake of the state's minimal interest.

Like the commercially grown produce in Pike, copyrighted works are produced for national and international commercial exchange. In Pike, Arizona was limiting the choices available to a cantaloupe producer in deciding how best to exploit its crop through interstate commerce. Selecting the best licensee for the movie production of a novel is as much a commercial business decision as is selecting the best site for a cantaloupe packing plant. "Best" can mean the most cost-effective, the most effective marketing, or most able to preserve the artistic integrity of a work. By preventing copyright authors from making independent business decisions about what is best for their works, Worth treats these authors as Arizona treated the cantaloupe growers in Pike. More directly, to the extent that out-of-state interests must pay more to Californians for California works (to get the approval of nonauthor spouses), California community property law is substantively identical to the Arizona cantaloupe law struck down in Pike. The commerce clause protects against interference with interstate commerce in goods; it does not distinguish between intangible goods, such as ideas, and tangible goods, such as cantaloupes. Under Pike, the Worth inter-

89. Id. at 142 (citation omitted).

90. Id. at 146. 
pretation of California community property law violates the commerce clause. ${ }^{91}$

The situation created by the Worth decision also parallels that at issue in an earlier Supreme Court case that also balanced state interests against interstate burdens, Dean Milk Co. v. Madison. ${ }^{92}$ In Dean Milk, the city of Madison, Wisconsin passed a health regulation forbidding the sale of milk in the city unless it was pasteurized within five miles of the center of the city at an approved pasteurizing plant. Although the ordinance at issue in Dean Milk imposed the same burdens on both in-state and out-of-state milk producers, the court noted explicitly that "[i]t is immaterial that Wisconsin milk from outside the Madison area is subjected to the same proscription as that moving in interstate commerce."93 Because the "practical effect" of the ordinance was to exclude wholesome milk from Illinois and prevent competition with milk producers outside Madison, the Supreme Court held that this ordinance plainly discriminated against interstate commerce. ${ }^{94}$

California's treatment of copyright ownership as community property is analogous in that it burdens in-state and out-of-state buyers of copyright equally. Just as it was immaterial in Dean Milk that some in-state producers were burdened along with the out-of-state producers, so is it immaterial that California burdens in-state buyers of copyrighted works along with out-of-state buyers. California gives benefits to one class of Californians, nonauthor spouses, at the expense of those who do business in the purchase and sale of copyrights. Hence, following the reasoning of Dean Milk, Worth's treatment of copyright ownership as community property violates the commerce clause.

91. See also Edgar v. MITE Corp., 457 U.S. 624 (1982) (plurality opinion), where the Court found an Ilinois statute regulating tender offers preempted by the Williams Act and unconstitutional under the commerce clause. One effect of the statute at issue in MITE was that an out-of-state corporation making a tender offer for another out-of-state corporation which had ten percent of its capital within Illinois had to comply with an Illinois procedural requirement when purchasing stock of the target owned by out-of-state residents. The Court found that the act "applies to corporations that are not incorporated in Illinois and have their principal place of business in other States. Illinois has no interest in regulating the internal affairs of foreign corporations." Id. at 645-46. In MITE, the burden Illinois imposed on interstate commerce was a set of tender offer regulations that had the "practical effect" of regulating out-of-state conduct. Id. at 643 (quoting Southern Pacific Co, v. Arizona, 325 U.S. 761, 775 (1945)). The Court held that the statute failed the commerce clause balancing test because it imposed burdens on interstate commerce that were excessive when compared to the interest Illinois sought to protect.

In $M I T E$, the effect of the statute was to regulate the acquisition of a non-Illinois company by another non-Ilinois company. By treating copyright ownership as community property, California forces non-Californians doing business with other non-Californians to alter their business behavior at substantial economic cost. Thus, pursuant to the Worth decision, California now regulates the commercial behavior of out-of-state parties in the same manner as Ilinois did with its unconstitutional tender offer statute. While the parts of the opinion discussing preemption based on the Williams Act and per se invalidity under the commerce clause were signed by only three and four justices, respectively, and thus do not bind the Court to its reasoning, see CTS Corp. v. Dynamics Corp. of America, 481 U.S. 69, 81 (1987) (narrowing the application of $M I T E$ to allow states to regulate tender offers for corporations incorporated within their boundaries), the part finding the statute unconstitutional under the commerce clause balancing test was signed by five justices.

92. 340 U.S. 349 (1951).

93. Id. at 354, n.4. (citation omitted).

94. Id. at 354 . 
California's interest is in economically protecting those spouses who generally are not primary breadwinners. Treating copyright ownership as community property by awarding ownership rights to nonauthor spouses is a burdensome way to serve California's interest in protecting nonbreadwinner spouses. Treating copyright ownership as community property does not grant nonauthor spouses a greater share of the income generated by the copyright. The only benefit such treatment gives nonauthor spouses is leverage in situations where the author spouse selects a less lucrative way to exploit a community property copyright. ${ }^{95}$ Worth burdens all transfers in order to protect nonauthor spouses in those few situations where the author spouse seeks to suppress income. Thus, the only benefit provided is small, confined to a subset of nonauthor spouses.

When applying the balancing test to California's treatment of copyright ownership as community property, an essential inquiry is whether California can promote its legitimate interest "as well" by some other means that has "a lesser impact" on interstate commerce. ${ }^{96}$ Prior to Worth, California served its family law interest by declaring the income generated by copyright-protected works produced during a marriage to be community property. Denying nonauthor spouses ownership rights under the copyright act would not affect the rights of these spouse to this income. If ownership of a copyright is not community property in terms of disposition and control, but rights to income are, nonauthor spouses do not lose this income stream in the event of divorce. Because the work is considered to be community property, income earned by the work after the dissolution of the marriage would be treated as community property (in the same way as rents from a community property building), not as separate property (such as income of one spouse after separation). ${ }^{97}$ Nonauthor spouses were well-protected economically prior to Worth, and the purposes of the community property system were served without giving nonauthor spouses co-owner status.

Because California's legitimate interest in regulating marital economic relationships within California can be adequately promoted without granting ownership rights to nonauthor spouses, this interest weighs against finding the statute, as interpreted by the Worth court, to be consistent with the commerce clause. Moreover, the benefit provided to nonauthor spouses by treating copyright ownership as community property is small, while the burdens placed on interstate commerce are significant. California's interest in granting co-owner status to nonauthor spouses is therefore not sufficient to justify the excessive

95. In the hypothetical used in Section II, supra, Worth gives the nonauthor spouse the power to push for a more lucrative deal where the author wants to license her work for a small budget art film. Giving the author spouse sole ownership of the copyright permits that spouse purposefully to suppress the commercial exploitation of community property works in the divorce context, simply to spite the nonauthor spouse, while providing no recourse for the nonauthor spouse.

96. Pike v. Bruce Church, Inc., 397 U.S. 137, 142 (1970).

97. CAL. CIV. CoDE $\S \S 5107-5108,5110,5118$ (West 1983 \& Supp. 1990). 
burdens placed on interstate commerce in copyrights, and as such is unconstitutional under the commerce clause balancing test as well as the per se test.

With this said, it must be acknowledged that the application of the commerce clause advocated here is not a foregone conclusion. To hold that under the commerce clause copyright ownership may not be treated as community property would break new ground. ${ }^{98}$ If, as one scholar has argued, ${ }^{99}$ and one Supreme Court justice has agreed, ${ }^{100}$ the Supreme Court's commerce clause jurisprudence is really only concerned with protectionist state measures, ${ }^{101}$ and the balancing test is only a veil for this purpose, treating copyright ownership as community property might withstand a commerce clause challenge. If, on the other hand, the Court were to apply the standards outlined in BrownForman, Pike, and Dean Milk, copyright as community property should fall.

\section{CONCLUSION}

Treating copyright ownership as community property is contrary to the basic policy of federal copyright law, which is to provide authors with incentives to create. Nonauthor spouses are protected adequately by granting a community property interest in the income derived from copyrights, as opposed to ownership rights. Furthermore, the transfer of ownership rights in copyrights to nonauthor spouses by operation of state community property law places an unacceptably large burden on interstate commerce and thus fails under commerce clause analysis.

Returning to the pre-Worth status quo by treating the income derived from the copyright as community property, but treating control of the copyright as the author's alone would (1) restore authors' incentives to create; (2) alleviate the concerns of out-of-state transferees; (3) eliminate the transfer standard dilemma by mooting the community property transfer standard; (4) adequately protect nonauthor spouses by granting them half of the income generated by copyrighted works attributable to the community; and (5) create no impermissible burdens on interstate commerce.

98. Traditionally, commerce clause cases have involved economic regulations, not the economic effects of the application of a family law statute.

99. Regan, The Supreme Court and State Protectionism: Making Sense of the Dormant Commerce Clause, 84 MICH. L. REV. 1091 (1986).

100. CTS Corp. v. Dynamics Corp. of America, 481 U.S. 69, 95 (1987) (Scalia, J. concurring); cf. Tyler Pipe Indus. v. Department of Revenue, 483 U.S. 232, 259-260 (1987) (Scalia, J. concurring in part and dissenting in part) ("IT]he practical results we have educed from the so-called 'negative' Commerce Clause form not a rock but a 'quagmire'. .. [ [O]ur applications of the doctrine have, not to put too fine a point on the matter, made no sense.") (citation omitted).

101. Regan, supra note 99, defines a statute as protectionist if (1) its purpose is to "improv[e] the competitive position" of in-state competitors over out-of-state competitors, and (2) it is "analogous in form to the traditional instruments of protectionism-the tariff, the quota, or the outright embargo ...." Id. at 1094-95. Obviously, California community property law does not readily fit this definition. 